\title{
NEW APPROACH FOR THE SYNTHESIS OF ARYLOXY 1,3-OXAZINES
}

\author{
Ghufran T. Sadeek ${ }^{1}$, Mohammad S. Al-jely ${ }^{2}{ }^{\mathbb{}}$, Neim H. Saleem ${ }^{3}$ \\ ${ }^{1,3}$ Chemistry Department, College of Education of Pure Science, Mosul university-Iraq \\ 2 Chemistry Department, College of Education for Girls, Mosul university-Iraq
}

DOI: https://doi.org/10.29121/granthaalayah.v8.i11.2020.2364

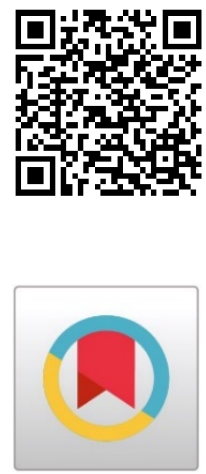

Article Type: Research Article

Article Citation: Ghufran T. Sadeek, Mohammad S. Al-jely, and Neim H. Saleem. (2020). NEW APPROACH FOR THE SYNTHESIS OF ARYLOXY 1,3-OXAZINES. International Journal of Research -GRANTHAALAYAH, 8(11), 137-144. https://doi.org/10.29121/granthaa layah.v8.i11.2020.2364

Received Date: 05 November 2020

Accepted Date: 30 November 2020

Keywords:

New

Approach

Aroyloxy

Oxazines

\begin{abstract}
Oxazine compounds have drew the attention of many researchers to find different approaches to the synthesis of this type of compounds according to the success of their use in a wide range of pharmaceutical application during the last decades .It is also for the difference reactivity of these analogues is exhaustively depicted and illustrates the rich versatility of this class of starting material. They proved to have most of actions of a combination of other drugs. We are herein investigate the synthesis of ethyl aryloxy acetate(S1-6) from the reaction of the corresponding ethyl bromo acetate with aryl phenols. These intermediates were cyclized with antharanilic acid affording the titled compounds.
\end{abstract}

\section{INTRODUCTION}

The chemistry of Oxazine becomes an important branch of heterocyclic compounds not just as synthetic intermediates but also due to the wide spectrum application of this type of compounds in medicine. There are many routes for their preparation were employed some of them from malonyl chloride [1], [2], Ethyl salicylate [3] Other methods of synthesis such as the work of N.R Taati et-al from the condensation of 3-amino propanol with carboxylic acids under solvent free condition [4]. Nadeem Siddiquia and his co-workers have reviewed the synthesis of some 1,3- oxazines from the condensation of different types of phenols such as hydroquinone, sulfone scaffold, Chavicol, Eugino l, Cardanol as well as ,salicylic acid with different amines in presence of formaldehyde and studied the biological activity of the synthesized compounds [5]. Ahmed El-Mekabaty in 2013 have reviewed versatile methods for oxazine synthesis from antharanilic acid and its derivatives [6]. Sayaji and Pravina B. Piste have reported the preparation of some 1,3- oxazine compounds from phenols and aromatic aldehydes in methanolic ammonia and have studied their anti-microbial activity against two gram positive and two gram negative bacteria .Antifungal activity was screened against Candidaalbicans, Aspergillus niger [7]. Some other researchers have cyclized chalcones into 1,3-oxazines using fly-ash and other catalysts. They also studied their antimicrobial activities. Against gram negative bacteria [8], [9]. Chaitra G. and Rohini RM have also synthesized 1,3-oxazine compounds from pyridyl

(C) 2020 The Author(s). This is an open access article distributed under the terms of the Creative Commons Attribution License, which permits unrestricted use, distribution, and reproduction in any medium, provided the original author and source are credited. 
chalcones and studied their Anti-Oxidant and Anti-Inflammatory activity [10].Among the other medical application of the oxazine compounds is the work of Vashundhra Sharma and his coworkers in synthesis and anti cancer study of 2-oxo-benzo [1], [4] oxazines [11]. J.C. Wouter. de Bruijna and his coworkers have studied the drug designing of 1,4- oxazines and found that their possible multitarget mechanism of the studied compounds as anti-inflammatory drug through quantitative structure-activity relationships (QSAR) [12]. Dadmohammad and his coworker have reported a green and efficient method for the synthesis of 1,3 oxazine compounds from aroyl chlorides and hydroxyl naphthaqunone in presence of ammonium thiocyanate at ambient temperature [13], In 1919-2020 researchers studied the synthesis of 1,3-oxazines and their human DNA topoisomerase I inhibitory potentials [14]. Recently Seyed Gholamhossein Mansouri et-al have synthesized naphtho [1,2-e] [1], [4] oxazines and studied their anticancer and antifungal activity [15]. According to the above utility and applications of this type of heterocyclic compounds and in continuing of our current drug discovery program [16], [17], [18] we have synthesize new 1,3- oxazine derivatives using new route of condensation protocol.

\section{EXPERIMENTAL}

All melting points were uncorrected using thermal SMP30 UK melting point apparatus .IR spectra were recorded using Alpha (ATR) instrument. ${ }^{1}$ HNMR spectra were recorded using Varian Agilent 499.53MHZ instrument, DMSO as internal solvent. All chemical were supplied by sigma -Aldrich, BHD and Fluka companies.

\section{Synthesis of ethyl substituted aryloxy acetate( $\left.s_{1-6}\right)$}

Using an elsewhere similar procedure of preparation of 1, 3, 4-oxadiazole Derivatives [19], A mixture of any indicated phenols $(1 \mathrm{mmol})$, ethyl bromoacetate $(0.122 \mathrm{~g}, 1 \mathrm{mmol})$ and anhydrous potassium carbonate $(0.55 \mathrm{~g}, 4 \mathrm{mmol})$ in $30 \mathrm{ml}$ of dry acetone was refluxed for $20 \mathrm{~h}$. the reaction mixture was evaporated under reduced pressure, The residue was dissolved in water.The final solution was extracted with ether, The ether extract was then dried over sodium sulphate anhydrous and filtered off .Evaporation of the solvent afforded the crude product which was crystallized from ethanol. Table(1) below shows the physical properties of the titled compounds.

Table 1: the physical properties of compounds $\left(\mathrm{S}_{1-6}\right)$

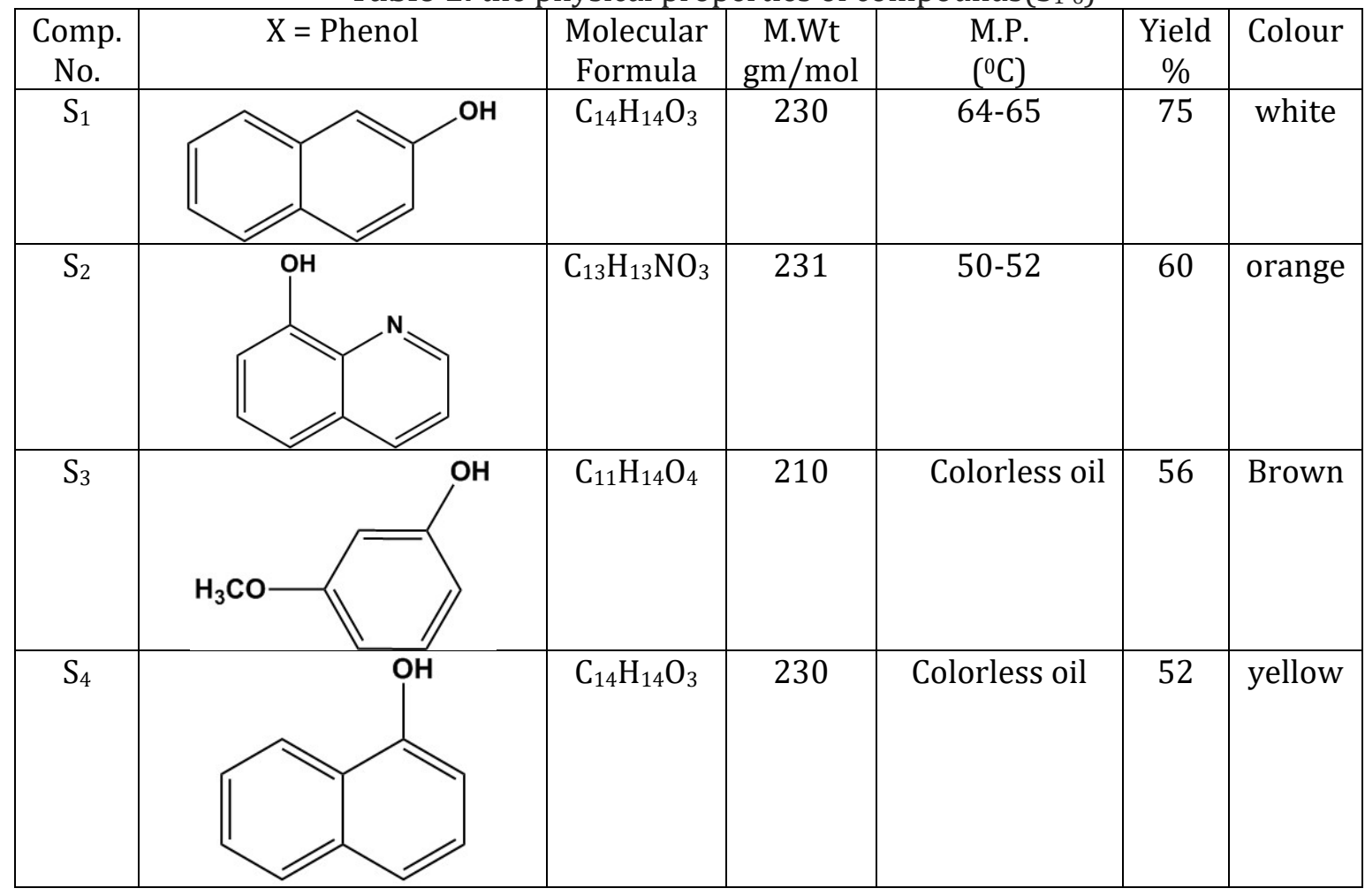


Ghufran T. Sadeek, Mohammad S. Al-jely, and Neim H. Saleem

\begin{tabular}{|l|l|l|l|l|l|l|}
\hline $\mathrm{S}_{5}$ & & & & & & \\
\hline $\mathrm{S}_{6}$ & & & & & & \\
\hline
\end{tabular}

\section{SYNTHESIS OF 2-ARYLOXY METHYL -3,1-BENZOXAZINE-4-ONE :( $\left.\mathbf{S}_{\text {7-12 }}\right)$}

Similar published procedure was used for the synthesis of the above compounds [20]. So, a quimolar amounts of anthranilic acid $(0.13 \mathrm{~g}, 1 \mathrm{mmol})$ and $\left(\mathrm{s}_{1-6}\right),(1 \mathrm{mmol})$ were heated at $\left(110^{\circ} \mathrm{C}\right)$ on sand bath for $5 \mathrm{hs}$. The reaction mixture was then treated by addition of $20 \mathrm{ml}$. ethanol, The crude precipitated product was filtered off and was then crystallized from petroleum ether(60-80) Table(2) below shows the physical properties of the synthesized compounds.

Table 2: Physical properties of compounds(S7-12)

\begin{tabular}{|c|c|c|c|c|c|c|}
\hline $\begin{array}{c}\text { Comp. } \\
\text { No. }\end{array}$ & $\begin{array}{c}\text { Molecular } \\
\text { Formula }\end{array}$ & $\begin{array}{c}\mathrm{M} \text {.Wt } \\
\text { gm/mol }\end{array}$ & $\begin{array}{c}\text { M.P. } \\
\left({ }^{\circ} \mathrm{C}\right)\end{array}$ & $\begin{array}{c}\text { Yield } \\
\%\end{array}$ & Colour \\
\hline $\mathrm{S}_{7}$ & & & & & \\
\hline
\end{tabular}




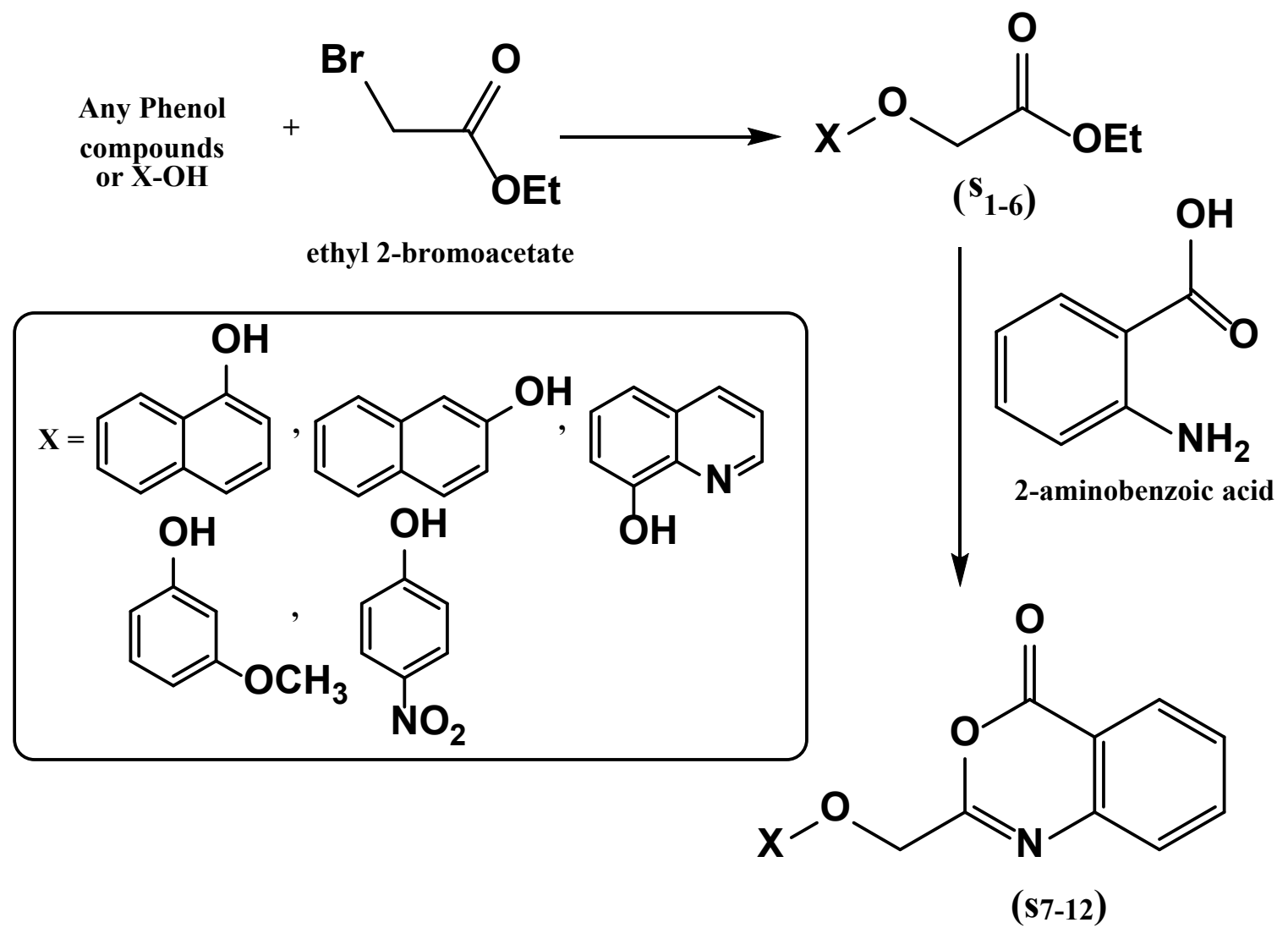

Scheme 1: The synthetic pathway for compounds (S1-12)

\section{RESULTS AND DISCUSSION}

\subsection{ETHYL SUBISTITUDED ARYLOXY ACETATE( $\left(\mathbf{S}_{1-6}\right)$}

These compounds(Scheme1) were synthesized using similar reported procedure ${ }^{102}$, and were characterized by the following main absorption bands $\left(\mathrm{U}_{\max } \mathrm{Cm}^{-1}\right)$ at(3003-3198)for C-H aromatic,(2835-2971) for C-H aliphatic,(1628-1687)for $\mathrm{C}=0,(1048-1166)$ for $\mathrm{C}-\mathrm{O}-\mathrm{C}$. The other absorption bands were shown in Table (3)

Table 3: IR spectral data for compounds $\left(\mathrm{s}_{1-6}\right)$

\begin{tabular}{|c|c|c|c|c|c|c|}
\hline $\begin{array}{c}\text { Comp. } \\
\text { No. }\end{array}$ & C-H Ar & C-H aliph. & $\mathrm{C}=\mathrm{O}$ & $\mathrm{C}-\mathrm{O}-\mathrm{C}$ & others \\
\hline $\mathrm{S}_{1}$ & & & & & & \\
\hline
\end{tabular}


Ghufran T. Sadeek, Mohammad S. Al-jely, and Neim H. Saleem

\begin{tabular}{|l|l|l|l|l|l|l|}
\hline $\mathrm{S}_{4}$ & 3064 & 2953,2835 & 1655 & 1048,1150 & $\ldots$ \\
\hline $\mathrm{S}_{5}$ & & & & & \\
\hline
\end{tabular}

${ }^{1} \mathrm{HNMR}$ for $\left(\mathrm{s}_{2}\right)$ compound as a representative of this series of intermediates showed triplet signal at ( $\left.2.46 \mathrm{ppm}\right)$ for $\mathrm{CH}_{3}$,q. signal at(3.34 ppm) for $\mathrm{CH}_{2}$ near Oxygen atom, doublet signal (with and opposite side of ring plane) resonated at (6.72-6.74 ppm) for $\mathrm{CH}_{2}$ between carbonyl group and Oxygen atom while quinolone ring protons appeared at ( $7.05,7.13,8.22,8.91 \mathrm{ppm})$

\subsection{2-ARYLOXY METHYL-3,1-BENZOXAZINE-4-ONE :(S}

These compounds (Scheme1) were synthesized using similar reported procedure as it was mentioned in the experimental part .They are characterized by the following main absorption bands $\left(\mathrm{U}_{\max } \mathrm{Cm}^{-1}\right)$ at $(1045-1145)$ for CO-C , (1452-1650)for $\mathrm{C}=\mathrm{C}$ aromatic,(1650-1684) for $\mathrm{C}=\mathrm{N},(1684-1711)$ for $\mathrm{C}=\mathrm{O}$ Table (4) showed the details of of all compounds spectral data below:

Table 4: IR spectral data for compounds $\left(\mathrm{s}_{7-12}\right)$

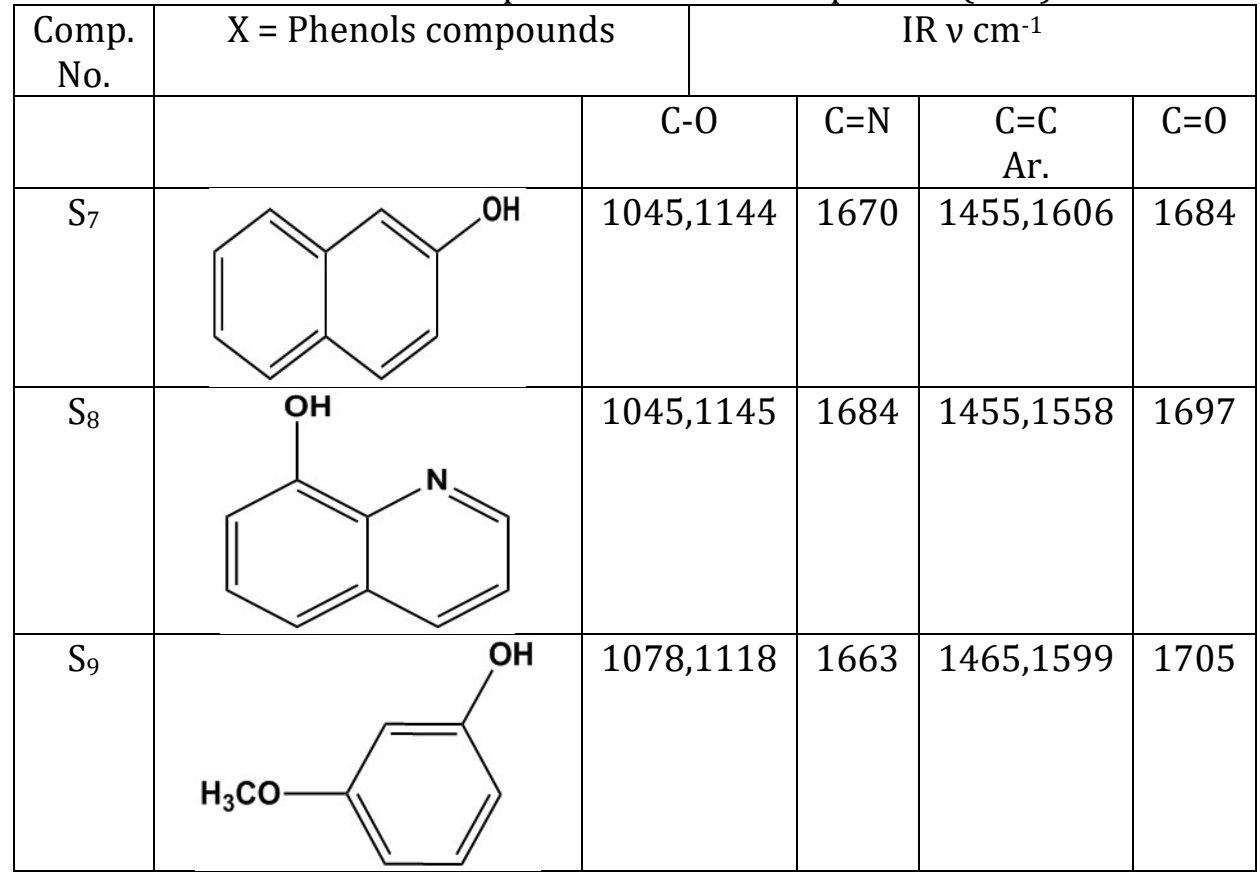




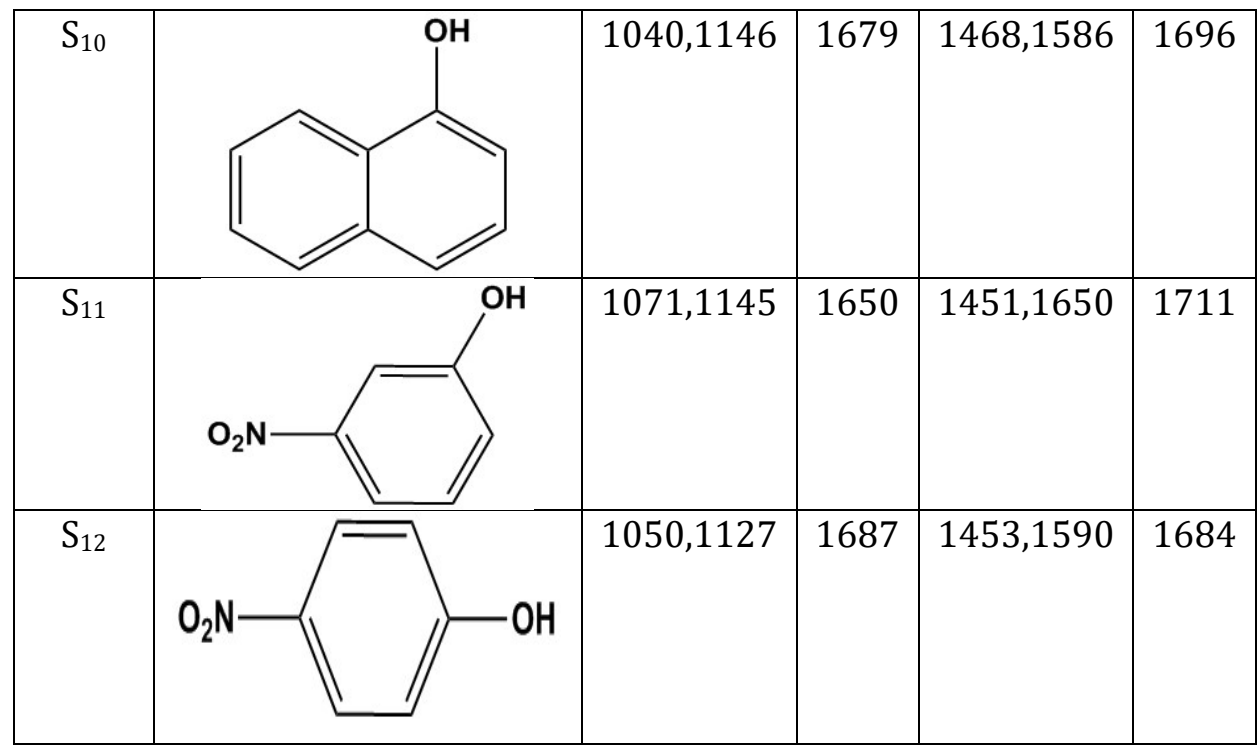

Some selected compounds $\left(\mathrm{S}_{8} a n d \mathrm{~S}_{10}\right)$ as representative of this series were studied and revealed the following NMR results. Their proton assignment were referred to the carbon number of the aromatic rings as shown below:

${ }^{1}$ HNMR for individual compounds were as follow:

\begin{tabular}{|c|c|c|}
\hline Como.no. & Structure compounds & $\begin{array}{c}\text { 1HNMR (PPM) } \\
\text { DMSO-d6 } \\
\end{array}$ \\
\hline $\mathrm{S}_{8}$ & & $\begin{array}{c}5.18(\mathrm{~s}, 2 \mathrm{H}) \mathrm{CH}_{2}-\mathrm{O} ;(7.04-7.05)\left(\mathrm{d}, 2 \mathrm{H}, \mathrm{C}_{12}, \mathrm{C}_{13}-\mathrm{H}\right) ;(7.34- \\
7.53)\left(\mathrm{t}, 2 \mathrm{H}, \mathrm{C}_{17}, \mathrm{C}_{18}-\mathrm{H}\right) ;(7.60-7.78)\left(\mathrm{m}, 2 \mathrm{H}, \mathrm{C}_{22}, \mathrm{C}_{23}-\mathrm{H}\right) \\
;(7.87-7.89)\left(\mathrm{m}, 1 \mathrm{H}, \mathrm{C}_{14}-\mathrm{H}\right) ;(8.04-8.05)\left(\mathrm{m}, 1 \mathrm{H}, \mathrm{C}_{11}-\mathrm{H}\right) \\
; 8.65\left(\mathrm{~m}, 1 \mathrm{H}, \mathrm{C}_{21}-\mathrm{H}\right)\end{array}$ \\
\hline $\mathrm{S}_{10}$ & & $\begin{array}{c}5.23(\mathrm{~S}, 2 \mathrm{H}) \mathrm{CH}_{2}-\mathrm{O} ;(7.0-7.02)\left(\mathrm{d}, 2 \mathrm{H}, \mathrm{C}_{21}, \mathrm{C}_{22}-\mathrm{H}\right) ;(7.31- \\
7.53)\left(\mathrm{m}, 1 \mathrm{H}, \mathrm{C}_{23}-\mathrm{H}\right) ;(7.64-7.68)\left(\mathrm{m}, 3 \mathrm{H}, \mathrm{C}_{11}, \mathrm{C}_{12}, \mathrm{C}_{13}-\mathrm{H}\right) \\
(7.73-7.69)\left(\mathrm{m}, 2 \mathrm{H}, \mathrm{C}_{17}, \mathrm{C}_{18}\right) ;(7.74-7.75)\left(\mathrm{m}, 1 \mathrm{H}, \mathrm{C}_{19},-\mathrm{H}\right)\end{array}$ \\
\hline
\end{tabular}

\section{SOURCES OF FUNDING}

This research received no specific grant from any funding agency in the public, commercial, or not-for-profit sectors.

\section{CONFLICT OF INTEREST}

The author have declared that no competing interests exist. 
Ghufran T. Sadeek, Mohammad S. Al-jely, and Neim H. Saleem

\section{ACKNOWLEDGMENT}

The authors would like to appreciate the Ministry of higher Education and research for offering Ghufran T. Sadeek a scholarschip and providing the facility to this work which apart of her PhD. Thesis.

\section{REFERENCES}

[1] M.SAl-Ajely, J.M.Ali Al-Rawi, J.A. Elvidge(1982)Heterocyclic syntheses with malonyl dichloride. Part 13. 6Chloro-4-hydroxy-2-oxopyran-3-carboxanilides from $\mathrm{N}$-sulphinylanilines and further reactions of malonyl dichloride with thiocyanates Journal of the Chemical Society Perkin Transact, vol.1,1575.

[2] M.S. Al-Ajelyand H.A. Basher (2007) Synthesis of Some Substituted Pyrano 1, 3-oxazin, Iraqi National Journal of Chemistry, vol. 28,695-703.

[3] M.S.Al-jelly(2013)Synthesis and Antiplatelet of 2-(ethyl amino acid esters), Amino pyridyl 1,3-oxzine8) ,J.of advance in Chemistry,vol.2,No.2,91.

[4] M.R. Taati, M. Mamaghani, N.O. Mahmoodi and A. oghmanifar(2009) A Simple Access to the Synthesis of 5,6Dihydro-4H-1,3-Oxazines Under Solvent-Free Conditions and Microwave Irradiation, Transactions C. Chemistry and Chemical Engineering, vol.16, No. 1, 17-21

[5] Nadeem Siddiquia, Ruhi Alia, M. Shamsher Alama, Waquar Ahsana(2010) Pharmacological Profile of Benzoxazines, J. Chem. Pharm. Res.,vol. 2,No4,309-316.

[6] A.El-Mekabaty (2013) Chemistry of 4H-3,1-Benzoxazin-4-ones, International Journal of Modern Organic Chemistry, vol.2No.2,81-121.

[7] S. Sayaji. Didwagh, B. Pravina. Piste(2013) Novel one - pot Synthesis and Antimicrobial Activity of 6-chloro2,4- diphenyl 3,4-dihydro-2H-1,3-benzoxazine derivatives, International Journal of ChemTech. Research, Vol.5, No.5, 2199-2203,

[8] G. Thirunarayanan, R. Sundararajan and R. Arulkumaran (2013) Aryl Chalcones as Efficient Precursors for Deriving0xazine: Solvent-free Synthesis and Antimicrobial Activities of some Oxazine-2-amines, International Letters of Chemistry, Physics and Astronomy. 23, 82-97.

[9] S. Sayaji. Didwagh and B. Pravina. Piste(2013) green synthesis of thiazine and oxazine derivatives - a short review, International Journal of Pharmaceutical Sciences and Research Vol. 4, Issue 6,2045-61.

[10] Chaitra G and Rohini RM (2018) Synthesis of 1,3-Oxazine derivative from Chalcone and Screening for their Anti-Oxidant and Anti-Inflammatory activity, International Research Journal of Pharmaceutical and Biosciences, 4 No.19-27.

[11] V. Sharma, K. Pradeep. Jaiswal , Mukesh saran, Dharmendra Kumar Yadav, Saloni , Manas Mathur , Ajit K. Swami , Sanjeev (2018) Discovery of C-3 Tethered 2-oxo-benzo[1,4]oxazines as Potent Antioxidants ;Bio inspired Based Design, Synthesis , Biological evaluation,Cytoxic and in Silico molecular docking studies, Frontires in chemistry,vol.6,56.

[12] J.C. Wouter. de Bruijna, Jos A. Hagemanb, Carla Araya-Cloutiera, Harry Gruppena,Jean-Paul Vinckena(2018) QSAR of 1,4-benzoxazin-3-one antimicrobials and their drug design perspectives, Bioorganic \& Medicinal Chemistry,vol.26,6105-6114.

[13] Dadmohammad Balouchzehi and \& Alireza Hassanabadi (2019) Synthesis of 2-Aryl-4-Thioxo-4HNaphtho[2,3-e] [1,3]Oxazine-5,10-Dione under Solvent-Free Conditions at Ambient Temperature, The Journal of the International Society for Polycyclic Aromatic Compounds, https://doi.org/10.1080.

[14] Egemen Foto, Çigdem Özen, Fatma Zilifd,Betül, Tekiner-Gülbaşillkay Yıldı, Esin Akı-Yalçın, Nuran Diril İsmail Yalçın(2020) Benzoxazines as new human topoisomerase I inhibitors and potential poisons, DARU Journal of Pharmaceutical Sciences,2865-73.

[15] Seyed Gholamhossein Mansouri, Hassan Zali-Boeini, Kamiar Zomorodian gBahman Khalvati, Razie Helali Pargali, Ali ehshahri, Hadi Amiri Rudbari,Mehdi Sahihi, Zahra Chavoshpour(2020) Arabian Journal of Chemistry, vol. 13, 1271-1282.

[16] IM Shaban1 and Mohammad S Al-Jelly (2019) Synthesis of Some Heterocyclic Compounds Derivedfrom Furfural Using Ultrasonic Waves, Bio medical J. of scientific and Technical research, vol. 22, No.1,16300-5.

[17] G.T. Sadeek, M.S. AlAjely, N. H. Saleem(2020) Synthesis of some oxazine compounds derived from phenols \& 8-hydroxy quinolone, Solid State Technology, Vol. 63 Issue: 5,3179-3192. 
[18] M. S .Al-Ajely and A. M .Noori(2020) An Efficient and Solvent Free Synthesis of N-Aryl2,3-Dihydro-4H naphtho-[2,1-e] 1,3-oxazines,Bio medical J. of scientific and Technical research, vol.29,No.3,22510-16.

[19] P. Panneerselvam and G.G. Ganesh, (2011), Synthesis and Antimicrobial Screening of Some Novel 2, 5Disubstituted 1, 3, 4-oxadiazole Derivatives,E- Journal of Chemistry, (8)S1:S149-S154.

[20] S.F. Mohamed, M. Youssef , Abd El-Galil E. Amr , E.R. Kotb , (2008) , Antimicrobial Activities of Some Synthesized Pyridines, Oxazines and Thiazoles from 3-Aryl-1-(2-naphthylprop-2-en-1-one), Scientia Pharmaceutica, vol.76,279-303 